\title{
Toward a Multi-Dimensional Ontology Model for Urban Planning
}

\author{
Fatimazahra Barramou' ${ }^{1}$, Khalifa Mansouri², Malika Addou' ${ }^{1}$ \\ ${ }^{1}$ Laboratory of Systems Engeneering (LaGes), Hassania School of Public Works, Casablanca, Morocco \\ ${ }^{2}$ Laboratory of Signals, Distributed Systems and Artificial Intelligence (SSDIA), Higher Normal School of Technical Education, \\ Mohammedia, Morocco \\ Email: f.barramou@gmail.com
}

How to cite this paper: Barramou, F., Mansouri, K. and Addou, M. (2020) Toward a Multi-Dimensional Ontology Model for Urban Planning. Journal of Geographic Information System, 12, 697-715. https://doi.org/10.4236/jgis.2020.126040

Received: October 14, 2020

Accepted: December 12, 2020

Published: December 15, 2020

Copyright (c) 2020 by author(s) and Scientific Research Publishing Inc. This work is licensed under the Creative Commons Attribution International License (CC BY 4.0).

http://creativecommons.org/licenses/by/4.0/

\begin{abstract}
In the recent past years, the major challenge facing scientists and researchers in the field of knowledge engineering is classifying and sharing geographic data with both computer and human. Ontology is one of the most important classification schemes that aim to make data machine-interpretable. In the literature, all ontology based models developed in the field of urban planning have some limits. First, they describe the nature of each parcel of the soil while ignoring other important components of urban planning such as services, infrastructure ... Secondly, these ontologies are developed according to legislation and regulations of the zone studied so they can't be used by some urban territories that have specific urban law such as Moroccan country. This paper presents a new multi-dimensional ontology model called LUP specifically developed to overcome this flaw. The main goal is to provide semantic land use descriptions according to four dimensions: zoning, services, infrastructure and easement and to define all LUP concepts within the Moroccan urban law. We illustrate the use of our proposed model with a case study by mapping a land use planning document within the area of Ainchock municipality of Casablanca city according to our model concepts.
\end{abstract}

\section{Keywords}

Urban Planning, Ontology, GIS, Knowledge, Interoperability

\section{Introduction}

Due to the huge amount of data that occurs from several systems and applications, it is necessary to classify this information in a meaningful way that can be machine-interpretable [1]. Classification consists of organizing data according to their characteristics [2]. The main objective of classification is to give semantics 
to the object. There are several classification schemes: data model, thesaurus, network and ontology [3].

The term ontology is borrowed from philosophy. Aristotle defined ontology as common features of objects and thus ontology meant an existing account of Existence [4]. Ederton in [5] demonstrates that ontology should not only present terminology but also knowledge about the world. Gruber defined ontology as "explicit specification of a conceptualization".

In contemporary knowledge engineering, ontology designates a hierarchical set of concepts articulated and defined according to explicit semantic relationships [6] [7]. Ontologies are in no way intended to store knowledge. This is the role of databases. Their function is only to make it possible to describe knowledge, while respecting some rules of logical consistency.

The concepts are most often intended to formalize and structure a set of knowledge, relating to a specified domain that can be called a universe of reference [8]. They organize, by giving them a logical structure, categories and terms making it possible to think of a domain and to express the knowledge that we have about it. The definition of concepts allows us to realize the grammar of an existing field of knowledge.

In general, ontology represents a set of concepts specified by formal definitions independent of any context of a certain problem domain [8] [9]. An ontology model is therefore a semantic formal model describing concepts about a specific domain, relationships and the constraints between them. In the literature, ontology has been used in many fields such as archeology [10], medicine [11], air quality [12], etc. In this article we will focus on the field of urban planning.

Urban planning has an important role in the economic development of territories. Its main objective is to improve the quality of life of residents by planning the future needs of the population in terms of housing, infrastructure, services, etc. [13]. Urban planning aims to develop a set of tools which are the urban planning documents to guarantee efficient management of land use and to promote the growth and development of urban and rural municipalities.

Among the most important urban planning documents, there is the Land Use Plan (LUP). The LUP is the regulatory town planning document that defines the right of the land use within the territories to which it applies [14]. It's a detailed document that aims to set the land use, the services to create and the infrastructure to implement across the municipality. The development of the LUP is done via a very complex process which involves on the one hand a set of stakeholders who are: town planners, architects, decision-makers, ministry in charge of town planning, external services, residents, ... and on the other hand, the heterogeneity of the data to be processed since it comes from different organizations and information systems.

To enable the communication and collaboration between all these stakeholders involved in the urban planning process, it is required to define an ontology model that describes all urban concepts with their relationships. In this research 
work, we propose an efficient ontology model for urban planning that aims to define urban area within four dimensions: zoning, infrastructure, services and easement.

The paper proceeds as follows: In Section 2, we provide related works. In Section 3 we introduce our proposed ontology model. In Section 4, we describe all concepts used in our model. In Section 5, we test the model with a case study, and Section 6 concludes and gives our future works.

\section{Related Work}

There are a large number of published researches that deals with the use of ontologies in the field of urban planning, however all these models have some limits as indicated in the following:

\subsection{Land Based Classification Standards (LBCS)}

The LBCS model was developed by the American Planning Association [15]. The objective of LBCS is to meet federal and state needs to establish a land use classification standard. Since the first version of LBCS which was released in 2000 and so far, several updates have been made periodically. LBCS has been used by several research projects on urban ontologies. N. Montenegro presents [16] a land use planning ontology based on the LBCS classification standards that he called LBCS:OWL2. This ontology is developed as a part of research project called City Induction that aims to develop a tool for urban planning and design [17]. The main goal of this ontology is to provide a semantic land use description using geo-spatial data. The taxonomy of LBCS:OWL2 was structured using the LBCS dimensions as classes. Then the concepts were defined by sub-classing each of the dimensions.

The limit of this ontology is that it describes the urban space only with the land use, the function of establishment, the structure of building, the site characteristics and the ownership. This ontology does not therefore allow us to represent all the concepts that exist in the land use plan such as infrastructure, easement, ...

\subsection{Towntology}

Towntology is a European project which was initiated by two laboratories, one in computer science and the other in urban planning at the INSA of Lyon [18]. This project is also known by the name COST C2 and it is supported by the COST (European Co-operation in the field of Scientific and Technical Research) [19]. The aim of the tontology project is to define ontology in the field of Urban Civil Engineering projetcs (UCE) in order to facilitate communication between information systems, urban planners and stakeholders at a European level [20]. The scientific objectives of this project are: defining a taxonomy of ontologies in the UCE field, develop a UCE ontology and present a visual editor to update concepts, develop guidelines for the construction of ontologies, analyze the im- 
pact of ontology in improving communication between stakeholders in the UCE domain [21]. C. Berdier presents in [22] three case studies on the construction of urban ontology using the Towntology prototype.

This ontology certainly allows us to define the urban space from a civil engineering project point of view. It thus presents a great limitation regarding the representation of the urban space with all its components.

\subsection{Other Research}

The authors of [23] present ontology of the institutional structure of an urban system by focusing on the actors, decisions and plans. The decision-making situations of the actors were characterized by participation, intentions and alternatives. This research is based on the principle that a city is not only a physical entity but also an institutional entity with a set of actors who govern it.

In [24], the authors present in this research an ontology based model to improve the communication between actors involved in urban planning projects. This ontology is focused on the modelling of the center of interest of actors and the semantic integration of the urban knowledge coming from multiple sources.

The HarmonISA project [25] aims to harmonize and automatically integrate land use data in the regions of Solvenia, Carinthia (Austria) and Friuli Venezia-Giulia (Italy). This ontology is suited to land cover than land use and is based on aerial photography data.

\subsection{Discussion}

Based on the study of related work conducted to better understand what is done in the literature regarding ontology models in the urban planning field, we noticed two limits of these models. First, the urban ontologies focus only on land use which describes the nature of each parcel of the soil while ignoring other important components of urban planning such as services, infrastructure... The urban planning of territories must therefore take into account not only the land use but also all the services and infrastructure necessary to improve the quality of life of citizens. Secondly, all the existing ontology models in the field of urban planning are developed according to legislation and regulations of the territories studied. For example, LBCS is developed to meet American federal and state needs to establish a land use classification standard. Towntology aims to facilitate the communication between urban planners at a European level. HarmonISA project initiated much ontology that corresponds to land cover classification systems in Italy and Austria.

To overcome this flow, we propose in this research work a new ontology model for urban planning that we called LUP ontology. The objective of this new model is first to present an ontology that describes all the components of land use planning according to four dimensions: zoning, services, infrastructure and easement. Secondly, LUP model must meet the Moroccan state needs to establish a land use classification according to the Moroccan urban legislation and 
regulations.

\section{Proposed Model}

\subsection{LUP Dimensions}

Our approach is based on the definition of the urban territory according to 4 different and complementary dimensions. LUP taxonomy is defined with a base class named LUP and four subclasses corresponding to the four LUP dimensions: Zoning, Infrastructure, Easement and Services Figure 1.

Zoning dimension refers to the distribution of the urban area in several classes according to the land use (Residential, industrial, etc.). Infrastructure dimension refers to the basic structured facilities (roads, railway, etc.) necessary for the needs of citizens. Easement dimension refers to the right of way area necessary for the installation of infrastructure. Services dimension refers to the public and private services of several types (sports, sanitary, school ...) necessary to meet the needs of the citizens.

\subsection{LUP Ontology Model}

To define our ontology model, we proceeded by sub-classing each dimension into several classes. Each class corresponds to a concept. The LUP ontology model is described by three main components: classes, relationships between classes and attributes that describe an individual class.

We defined about 100 classes in our model. Every class is defined by name, code and description. The taxonomy was defined according to the following rules: Every dimension subclass will have an individual with the same name and all classes are disjoint and individuals are also declared different from each other. Figure 2 shows our ontology based model for land use planning:

There are several ontology editors and framework for building ontology like HOZO, OntoEdit, and Protege. We choose using Protégé [26] since this tool allows reading and saving ontologies in most formats RDF, RDFS, OWL, etc. and also Protege is recognized for his ability to work on ontologies of large dimensions [27]. Figure 3 shows our model class hierarchy.

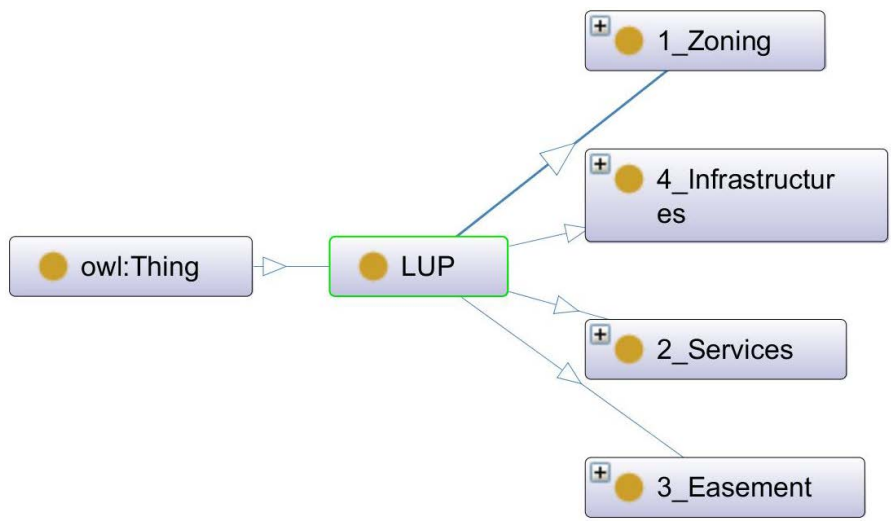

Figure 1. LUP multi-dimensional model. 


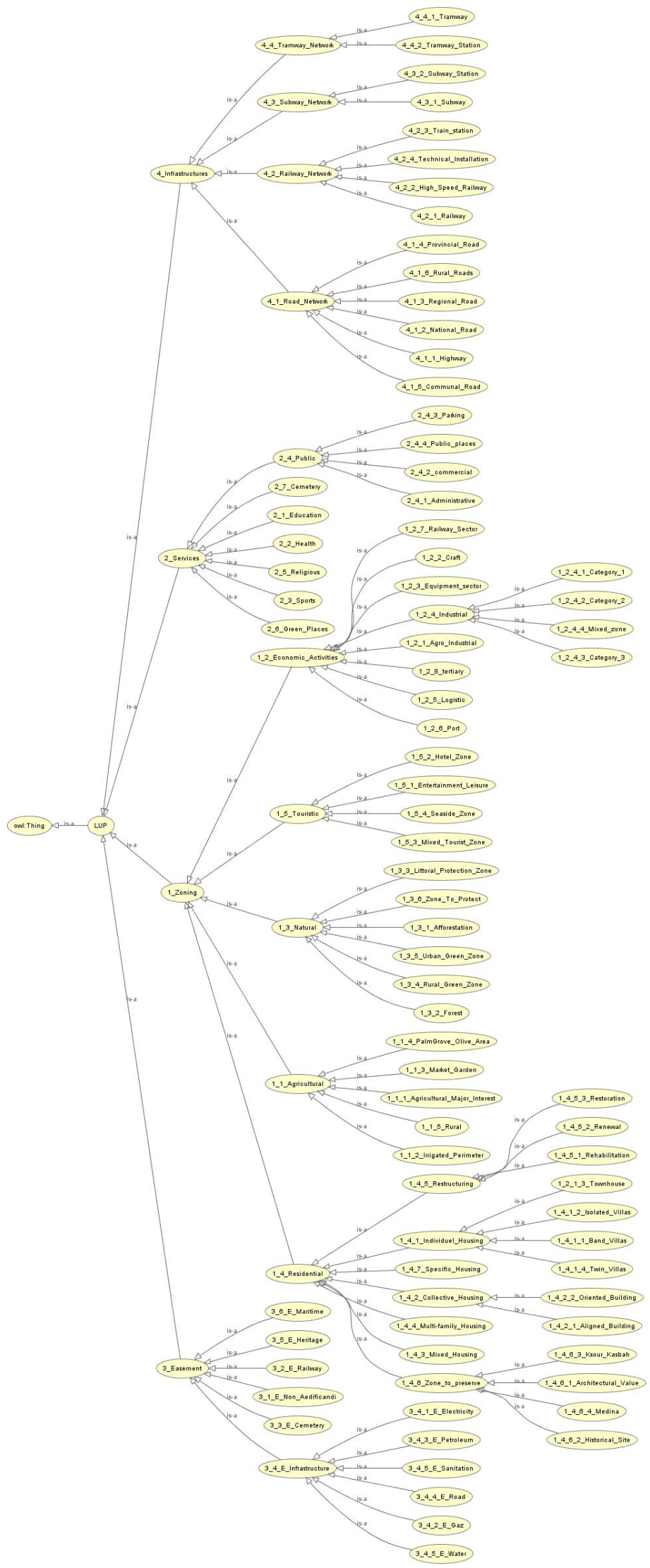

Figure 2. LUP ontology model. 


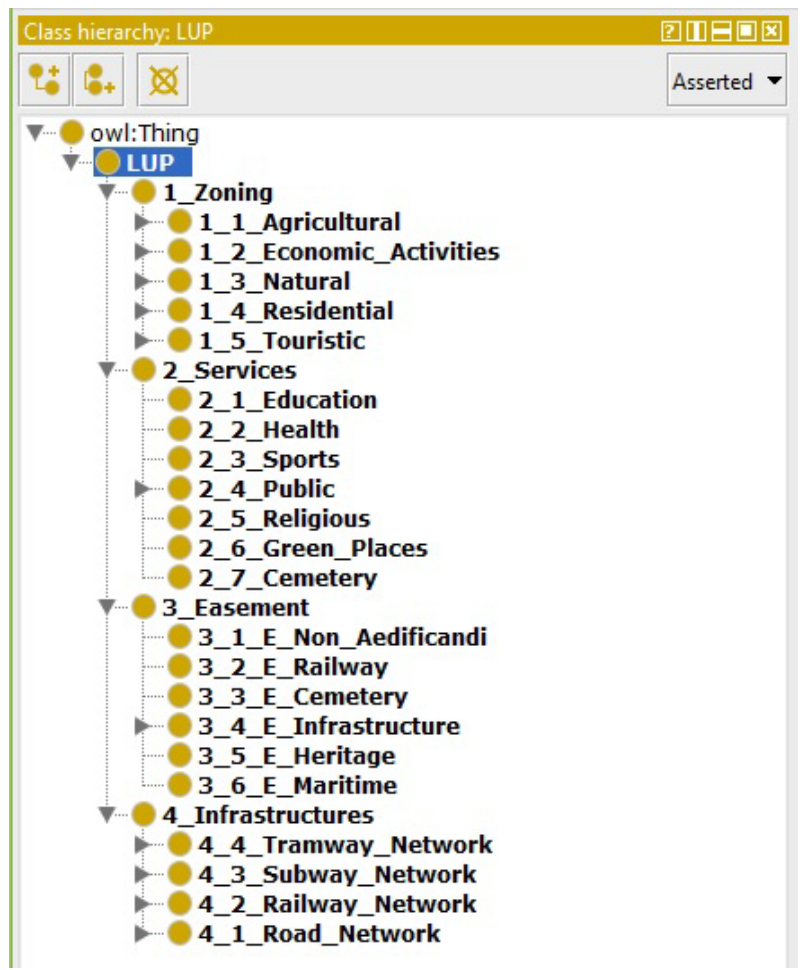

Figure 3. LUP class hierarchy in protege.

\section{Lup Concepts}

\subsection{Zoning Concepts}

Zoning is an important class in our model. It represents the land use of each parcel of the urban area. The zoning sub-classes are determined based on specified criteria. In the zoning dimension, we defined six classes that describe the land use:

\subsubsection{Agricultural Zoning Concept}

The agricultural zoning includes all the lands used for agriculture. It can contain plots on which can be realized the housing of farmers and the annex buildings essential to the agricultural exploitation. The agricultural zoning has five sub-classes as shown in Table 1.

\subsubsection{Residential Zoning Concept}

The residential zoning represents all the areas dedicated to housing in the urban development plan. The residential zoning has mainly seven subclasses as shown in Table 2.

\subsubsection{Natural Zoning Concept}

The natural zoning refers to all the areas which have a natural aspect to be protected from an environmental and ecological point of view. This zoning is very important in urban planning since it allows making a balance with the urban and residential zoning. Natural zoning has six sub-classes as shown in Table 3. 


\subsubsection{Touristic Zoning Concept}

The tourist zoning refers to the area reserved for the development of tourist facilities in the form of hotels, summer centers and tourist residences, guesthouses. Tourist zoning has fur sub-classes as shown in Table 4.

Table 1. Agricultural zoning concepts.

\begin{tabular}{|c|c|}
\hline Concept & Description \\
\hline Agricultural Major Interest & $\begin{array}{l}\text { Refers to an area with a special agriculture protection to } \\
\text { preserve the current zone agricultural character }\end{array}$ \\
\hline Irrigated Perimeter & $\begin{array}{c}\text { Refers to areas irrigated in particular by dams and } \\
\text { groundwater resources. }\end{array}$ \\
\hline Market Garden & $\begin{array}{l}\text { Refers to the area including all land for strictly agricultural } \\
\text { purposes: the entire peri-urban area where the agricultural } \\
\text { and environmental potential must be safeguarded. }\end{array}$ \\
\hline Palm Grove Olive Area & $\begin{array}{l}\text { Refers to areas that may not be subject to any construction. } \\
\text { They correspond generally to areas already planted by palm } \\
\text { trees and olive trees with an absolute protection. }\end{array}$ \\
\hline Rural & $\begin{array}{l}\text { Refers to all areas with strictly agricultural purposes. It is made } \\
\text { up of plots on which can be built the housing of the farmers and } \\
\text { the annex buildings essential to the agricultural activity }\end{array}$ \\
\hline
\end{tabular}

Table 2. Residential zoning concepts.

\begin{tabular}{|c|c|}
\hline Concept & Meaning \\
\hline Individual housing & $\begin{array}{l}\text { This area is characterized with low habitat density. } \\
\text { Individual housing class has three sub-classes: } \\
\text { Isolated villa, Band villa and Townhouses. }\end{array}$ \\
\hline Collective housing & $\begin{array}{l}\text { Refers to a set of buildings area with common green spaces. } \\
\text { Collective housing class has two sub-classes: } \\
\text { Aligned buildings and Oriented Buildings. }\end{array}$ \\
\hline Multi family housing & $\begin{array}{c}\text { Refers to an urban area which contains already existing housing } \\
\text { sectors. It's possible to have in this area commercial activities, } \\
\text { offices, tertiary activities, services, etc. }\end{array}$ \\
\hline Mixed housing & $\begin{array}{c}\text { Refers to area that contains existing housing sectors and new } \\
\text { buildings projected in the development plan. Installation } \\
\text { of services is allowed in this area. }\end{array}$ \\
\hline Restructuring & $\begin{array}{c}\text { Refers to area with irregular housing that should be planned } \\
\text { with restructuring plans. This class has four sub-classes: } \\
\text { Rehabilitation, Renewal and Restoration. }\end{array}$ \\
\hline Specific housing & $\begin{array}{l}\text { Refers to urban area with specific regulations according } \\
\text { to the specificity of each region. }\end{array}$ \\
\hline Zone to preserve & $\begin{array}{c}\text { Refers to urban area that has great heritage and architectural value. } \\
\text { This class includes four sub-classes: Medina, Ksour-Kasbah, } \\
\text { Architectural value and Historic site }\end{array}$ \\
\hline
\end{tabular}


Table 3. Natural zoning concepts.

\begin{tabular}{|c|c|}
\hline Concept & Meaning \\
\hline Forest & $\begin{array}{l}\text { Refers to unequipped land, which constitutes natural environments } \\
\text { that should be protected because of the quality of their landscapes, } \\
\text { in particular from an ecological point of view. }\end{array}$ \\
\hline Afforestation zone & $\begin{array}{l}\text { Refers to an area made up of green spaces and afforestation } \\
\text { that should be protected and which can be developed to } \\
\text { become a garden or an urban park. }\end{array}$ \\
\hline Zone to protect & $\begin{array}{l}\text { Refers to a site made up of natural spaces that should be protected because } \\
\text { of the quality of the landscapes and the character of the natural elements } \\
\text { that compose them. In this area, all construction is prohibited. }\end{array}$ \\
\hline Rural Green Zone & $\begin{array}{l}\text { It's an open and unbuilt area. It plays a main role in the balance } \\
\text { between the objectives of protection and the development of the } \\
\text { municipal territory. }\end{array}$ \\
\hline Urban Green Zone & $\begin{array}{l}\text { It's an open and unbuilt space in the municipality territory. } \\
\text { It contributes in particular to reducing the risk of flooding. }\end{array}$ \\
\hline $\begin{array}{l}\text { Littoral Protection } \\
\text { Zone }\end{array}$ & $\begin{array}{l}\text { It is an area with an absolute protection. No construction or fixed or } \\
\text { removable installation is authorized in this area. Only work of reinforcement } \\
\text { and rehabilitation inside the existing buildings are authorized }\end{array}$ \\
\hline
\end{tabular}

Table 4. Touristic zoning concepts.

\begin{tabular}{|c|c|}
\hline Concept & Meaning \\
\hline Entertainment Leisure & $\begin{array}{l}\text { Refers to a tourist development zone reserved for hotels, and } \\
\text { tourist establishments, leisure and entertainment activities. }\end{array}$ \\
\hline Hotel Zone & $\begin{array}{c}\text { It is an urban area reserved for hotels. All industrial establishments, } \\
\text { offices and depots, quarry exploitation, Housing estate and buildings } \\
\text { construction are prohibited in the area. }\end{array}$ \\
\hline Seaside Zone & $\begin{array}{l}\text { Refers to the coastal area of the country (outside the littoral } \\
\text { protection zone). Any construction in this area must be done } \\
\text { with a specific sectoral development study }\end{array}$ \\
\hline Mixed Tourist Zone & $\begin{array}{l}\text { It's an area reserved for tourism, leisure and exhibition area, the } \\
\text { location of leisure facilities, hotel and exhibition establishments as } \\
\text { well as representations of large commercial enterprises is allowed. }\end{array}$ \\
\hline
\end{tabular}

\subsubsection{Economic Activities Concept}

Economic activity zoning is the essential complement to the residential zoning. It can represent industrial, craft, tertiary and commercial activities. This zoning has eight sub-classes as shown in Table 5.

\subsection{Easement Concepts}

Easement is the second dimension in our model. It represents the rights-of-way necessary for the installation of infrastructures as well as for the heritage protection zone, cemeteries, etc. The basis of an easement is the geographical area within which the easement applies. In the easement dimension, we defined six sub-classes as shown in Table 6. 
Table 5. Touristic zoning concepts.

\begin{tabular}{|c|c|}
\hline Concept & Meaning \\
\hline Industrial activity & $\begin{array}{l}\text { Refers to all the industrial activities allowed in the city. It has four sub } \\
\text { classes: Category 1: refers to industrial activities having the most } \\
\text { disadvantages (in terms of danger of nuisance and unsanitary conditions) } \\
\text { Category 2: The disadvantages of this category are harmful fumes, } \\
\text { water damage and the danger of fire. Category } 3 \text { : The only risk in this } \\
\text { activity is the danger of is fire. Mixed zone: refers to zone assigned } \\
\text { to activity of category } 1 \text { and } 2 .\end{array}$ \\
\hline Craft activity & $\begin{array}{l}\text { This zone is reserved for traditional craft activities with local } \\
\text { traditional products and manufacturing methods. }\end{array}$ \\
\hline Logistic activity & $\begin{array}{l}\text { This zone is reserved to receive logistics projects (storage, } \\
\text { distribution, logistics service) and all equipment necessary } \\
\text { for the functioning of this sector. }\end{array}$ \\
\hline Port's activity & $\begin{array}{l}\text { This zone is reserved for activities related to the port. Only the } \\
\text { installations and constructions necessary for activities related } \\
\text { to port establishments are authorized }\end{array}$ \\
\hline Railway activity & $\begin{array}{c}\text { Refers to a zone of specialized activities, used by the public rail } \\
\text { service in the urban sector. It is reserved for railway } \\
\text { constructions and installations. }\end{array}$ \\
\hline Agroindustrial activity & $\begin{array}{l}\text { This zone is reserved for non-polluting } \\
\text { agro-industrial establishments. }\end{array}$ \\
\hline Tertiary activity & $\begin{array}{l}\text { This zone is reserved for all the commerce and services given to } \\
\text { the citizen such as banks, commerce, offices, showrooms, etc. }\end{array}$ \\
\hline Equipment sector & $\begin{array}{c}\text { This zone is intended to the construction of large indoor and } \\
\text { outdoor equipment. These large facilities are intended to receive } \\
\text { the public, and to provide services of all kinds: Education, } \\
\text { public health, sports... }\end{array}$ \\
\hline
\end{tabular}

Table 6. Easement concepts.

Concept
Meaning
E-Non Aedificandi $\begin{array}{r}\text { This area is reserved to preserve certain rough urban spaces, flooding } \\ \text { spaces or basic infrastructure sites, from any superstructure } \\ \text { construction. Therefore, any land use is prohibited there. }\end{array}$
It refers to a non-constructible area that
surrounds the cemetery.
E-Cemetery
Refers to area reserved for the protection of historical and
archaeological heritage around historical sites.
Refers to a non-constructible band running
along both sides of the railway line.
Refers to the easements relating to the passage of water distribution
infrastructure, sanitation, electric energy, gas, etc. This class has
six sub-classes: E-Electricity, E-Water, E-Sanitation,
E-Gaz and E-Telecom




\subsection{Services Concepts}

Services dimension is the third dimension in our ontology model. It refers to the existing and planned services in the urban system. Each municipality contains a set of services necessary to meet the needs of citizens such as schools, hospitals, administrations, services, etc. With the increase in the population, urban planning must anticipate the needs in terms of public services according to a socio-economic study. Services dimension is represented by a class which has several subclasses as shown in Table 7.

\subsection{Infrastructure Concepts}

The economic, social and cultural development of urban systems presupposes the presence of a solid and diversified infrastructure network. The role of urban planning is to plan the city's need for infrastructure over the long term. In our model, the infrastructure dimension allows us to define all the concepts related to this domain. Infrastructure is represented by a class that has four sub-classes as shown in Table 8.

Table 7. Services concepts.

Concept
Education
$\begin{array}{r}\text { Refers to all educational facilities: public or private primary schools, } \\ \text { elementary schools, middle schools, higher education institution. }\end{array}$
Health
Refers to all public or private health service. For example:
hospitals, health center, polyclinic ...

Table 8. Infrastructure concepts.

\begin{tabular}{|c|c|}
\hline Concept & Meaning \\
\hline Road network & $\begin{array}{c}\text { Refers to all the land traffic routes allowing the transport of motor vehicles. } \\
\text { It consists of an interweaving of networks of different sizes and capacities. } \\
\text { It has several sub classes: Highway, National road, Regional road, } \\
\text { Provincial road, Communal road and Rural road }\end{array}$ \\
\hline Railway network & $\begin{array}{c}\text { Refers to a set of railway lines, stations and various technical installation } \\
\text { which allow the circulation of train. It has the following sub-classes: } \\
\text { Train station, Technical installation, Railway, HTS line. }\end{array}$ \\
\hline Tramway network & $\begin{array}{l}\text { Refers to the networks and lines operated by tramcars. This class } \\
\text { has two sub-classes: Tramway and Tramway Station. }\end{array}$ \\
\hline Subway network & $\begin{array}{l}\text { Refers to an electric railway network operating below the surface of the } \\
\text { ground. This class has two sub-classes: Subway and Subway Station. }\end{array}$ \\
\hline
\end{tabular}




\section{Case Study}

In [28], author presents two approaches for ontologies evaluation. The first approach is based on criteria. Ontology evaluation is defined in this approach with criteria such as computational efficiency [29], precision, recall, and congruency [30]. The second approach is based on strategy. For the ontology evaluation by strategy, authors in [31] differentiate empirical validation from validation by example. Empirical validation is done by presenting an experimental procedure or a case study. While validation by example is done by presenting some real world examples to illustrate relevant ontology concepts.

In our research, LUP ontology evaluation is preceded with empirical validation approach. A case study was performed to assess the ontology. We chose to apply our model to the city of Casablanca which is the largest urban center in Morocco. The area of study is the municipality "Ainchock". We will discuss the use of ontologies in the context of Ainchock land-use planning. The first step towards data integration was to perform ontology mapping. We first studied land use planning document of Ainchock which is composed with the local geographic data provided in shapefile format and the document of the urban regulation of Ainchock. This document provides a good understanding of the meaning of each entity class with the associated urban rules. We did then a comparison between local data model of land use planning document of Ainchock and equivalent classes in our LUP model. Mapping is done by "same As" axioms to relate similar concepts. Table 9 highlights the mapping classes:

The database implementation of LUP model is done by adding four feature classes which correspond to the four dimensions of our LUP model as shown in Figure 4.

Each dimension is represented by a feature class that has attributes representing information about the zoning. The total number of attributes in each feature class should equal the number of hierarchical sub-classes. For example, Figure 5 shows the attribute table of the feature class Zoning. Each zoning entity has three attributes describing the land use: zoning_level1, zoning_level2 et zoning_level3. LUP model can be extended or customized easily. Dimensions can be added or dropped by adding or removing feature classes. Sub-classes may be added or dropped as needed by adding or dropping attributes.

We filled the geodatabase from the geographic data of the land use planning of Ain Chock using ArcGIS software. Figure 6 shows land use planning of Ainchock according to the four LUP model dimensions.

We present in Figure 7 the final result of mapping Ainchock municipality according to our LUP multi-dimensional model.

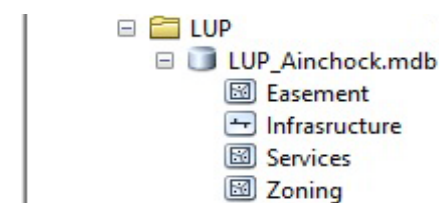

Figure 4. LUP database implementation in ArcGIS. 
Table 9. Comparison between local data model and LUP model.

\begin{tabular}{|c|c|c|}
\hline Local data model & $\equiv$ & LUP model \\
\hline DB_Sectors_Ainchock & $\equiv$ & 1_Zoning \\
\hline Sector C & $\equiv$ & 1_4_2_Collective Housing \\
\hline Sector B & $\equiv$ & 1_4_3_Mixed Housing \\
\hline Sector E1 & $\equiv$ & 1_4_4Multi family Housing \\
\hline Sector E2 & $\equiv$ & 1_4_4Multi family Housing \\
\hline Sector D3S & $\equiv$ & 1_2_1_3_Townhouses \\
\hline Sector D1 & $\equiv$ & 1_4_1_2_Isolated Villa \\
\hline Sector D2 & $\equiv$ & 1_4_1_1_Band Villa \\
\hline Sector I8 & $\equiv$ & 1_2_5_Logistic \\
\hline Sector I5 & $\equiv$ & 1_2_8_Tertiary \\
\hline Sector I2 & $\equiv$ & 1_2_4_2_Category 2 \\
\hline Sector I3 & $\equiv$ & 1_2_4_3_Category 3 \\
\hline Sector C V & $\equiv$ & 1_3_5_Urban Green Zone \\
\hline DB_equipement_Ainchock & $\equiv$ & 2_Services \\
\hline School & $\equiv$ & 2_1_Education \\
\hline high school & $\equiv$ & 2_1_Education \\
\hline University & $\equiv$ & 2_1_Education \\
\hline Hospital & $\equiv$ & 2_2_Health \\
\hline Sports ground & $\equiv$ & 2_3_Sport \\
\hline Police station & $\equiv$ & 2_4_1_Public \\
\hline Market place & $\equiv$ & 2_4_2_Commercial \\
\hline Parking & $\equiv$ & 2_4_3_Parking \\
\hline Place & $\equiv$ & 2_4_4_Public_Places \\
\hline Mosque & $\equiv$ & 2_5_Religious \\
\hline Garden & $\equiv$ & 2_6_Green_Places \\
\hline DB_ZNAE_Ainchock & $\equiv$ & 3_Easement \\
\hline ZNAE & $\equiv$ & 3_1_E_Non_Aedificandi \\
\hline Servitude_Route & $\equiv$ & 3_4_4_E_Road \\
\hline Servitude_Train & $\equiv$ & 3_2_E_Railway \\
\hline DB_Voies_Ainchoxk & $\equiv$ & 4_Infrastructure \\
\hline Voie_ferree & $\equiv$ & 4_2_1_Railway \\
\hline Tram & $\equiv$ & 4_4_1_Tramway \\
\hline Voirie & $\equiv$ & 4_1_5_Communal_Road \\
\hline
\end{tabular}

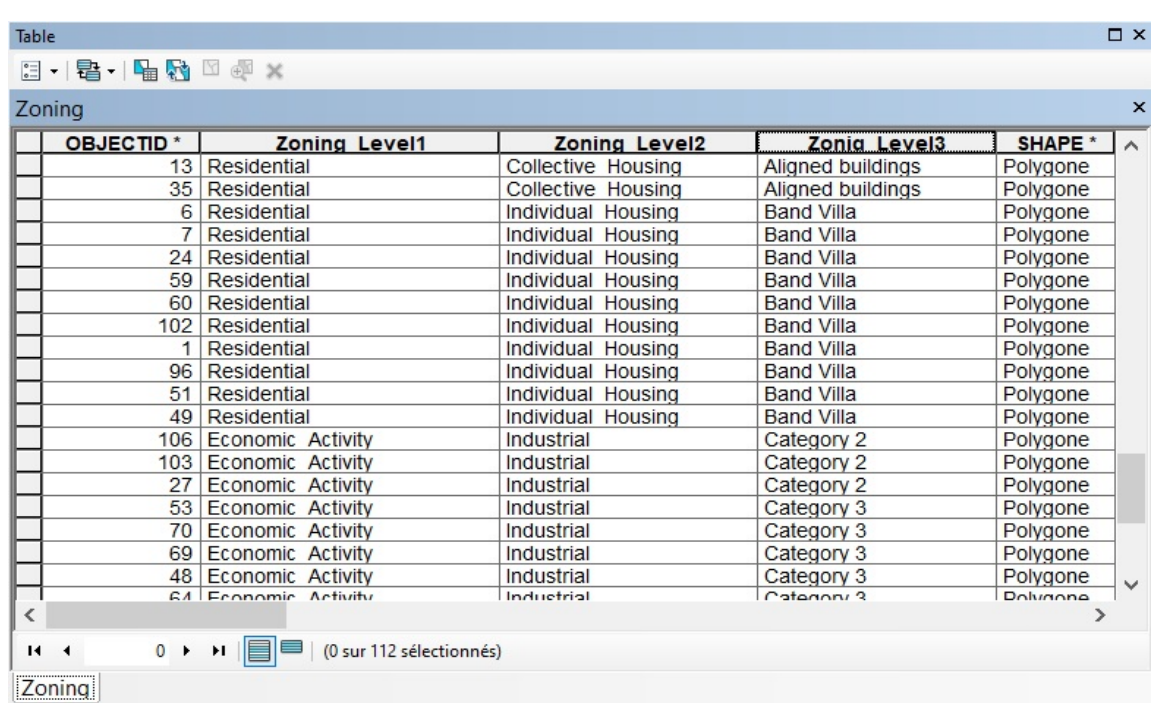

Figure 5. Attribute table of the feature class Zoning. 


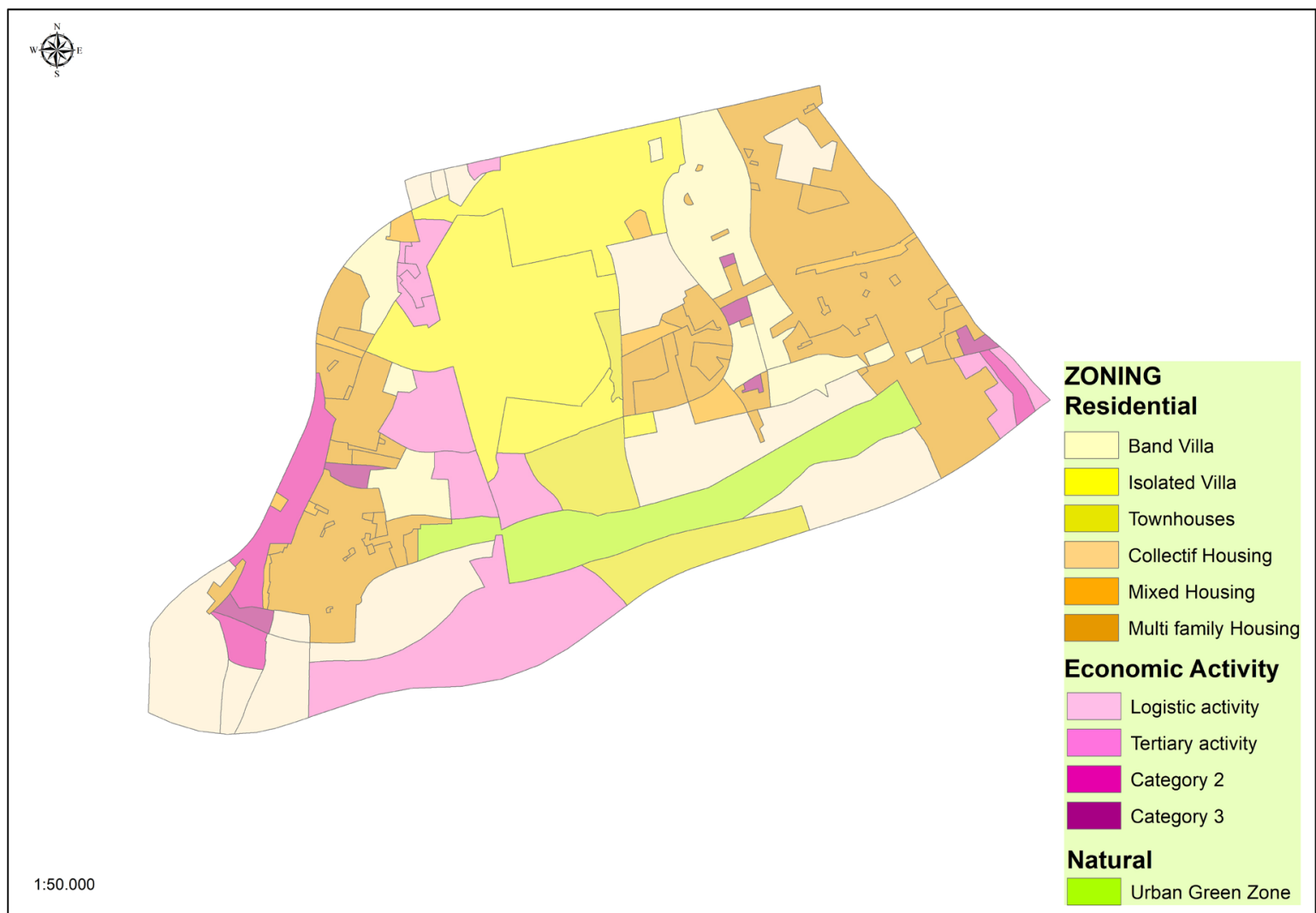

(a)

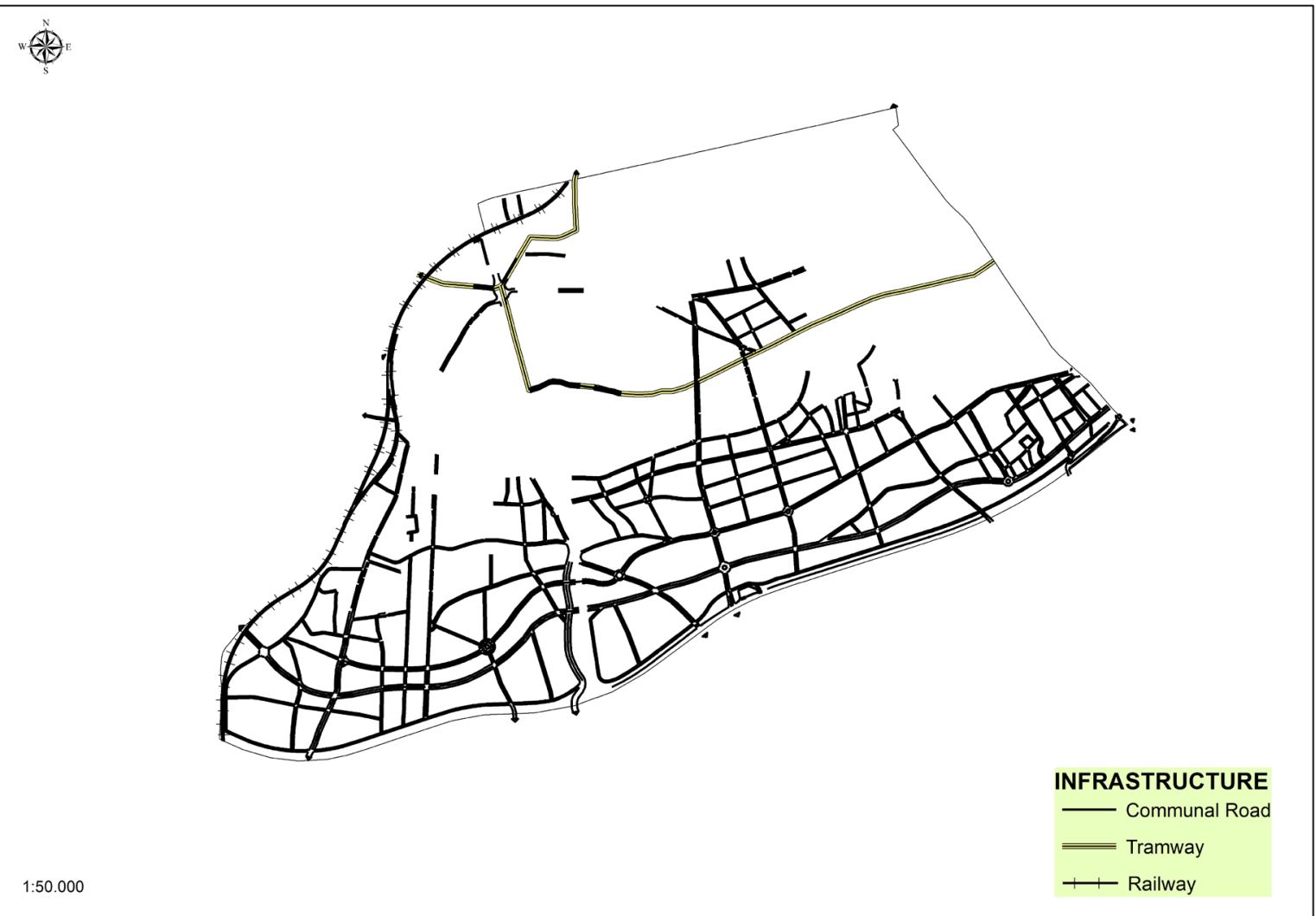

(b) 


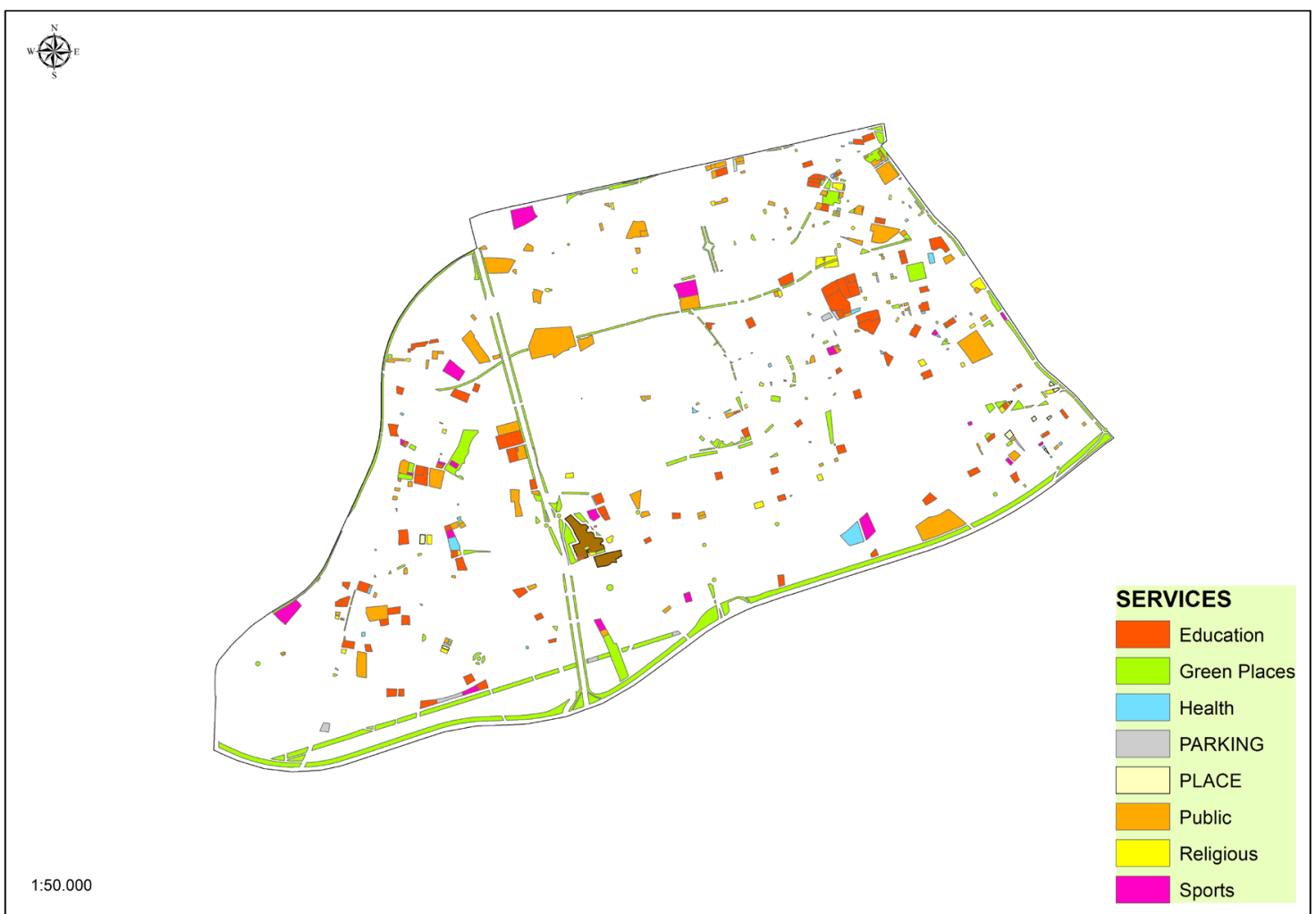

(c)

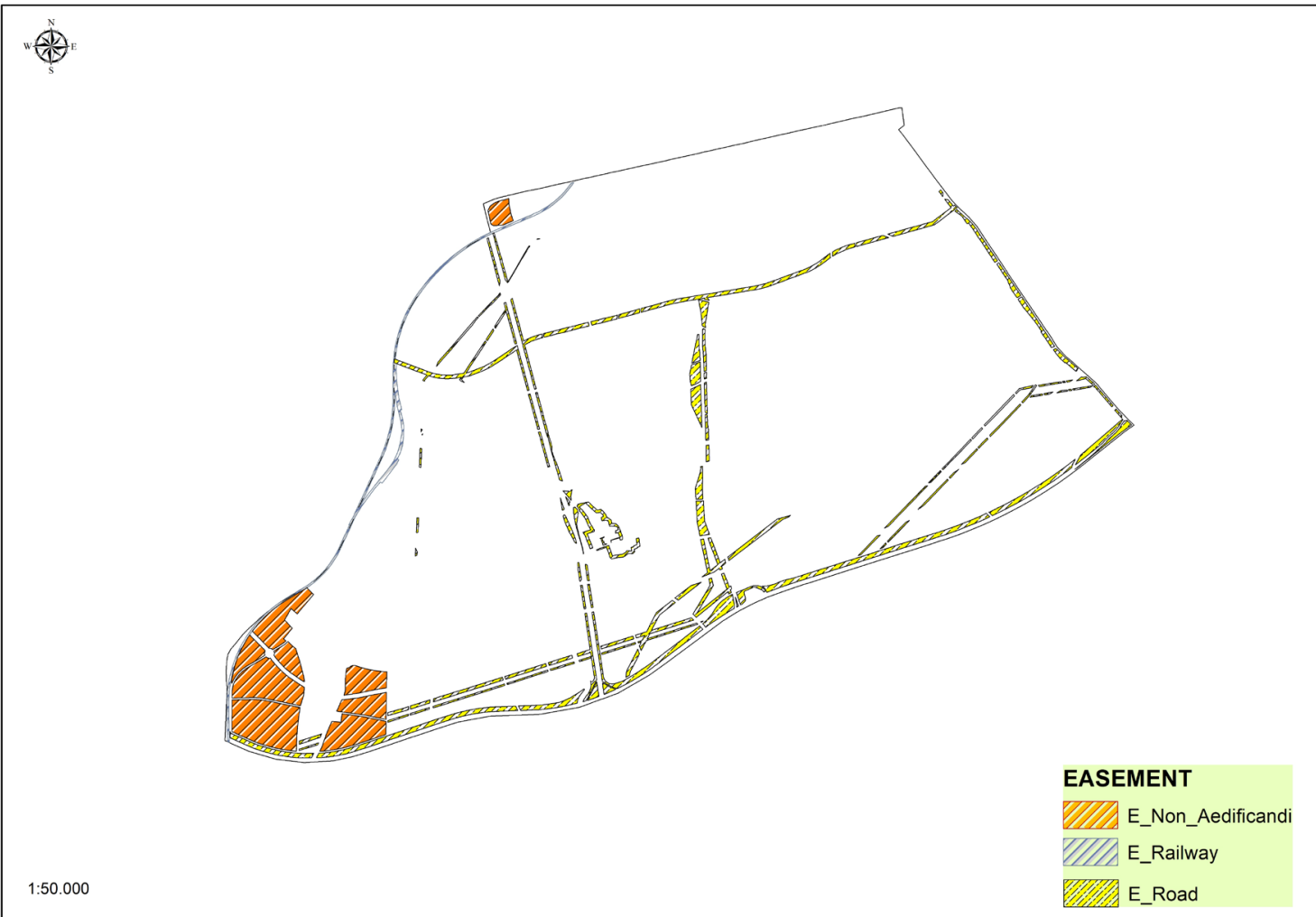

(d)

Figure 6. (a) Mapping zoning dimension of Ainchock; (b) Mapping infrastructure dimension of Ainchock; (c) Mapping services dimension of Ainchock; (d) Mapping easement dimension of Ainchock. 


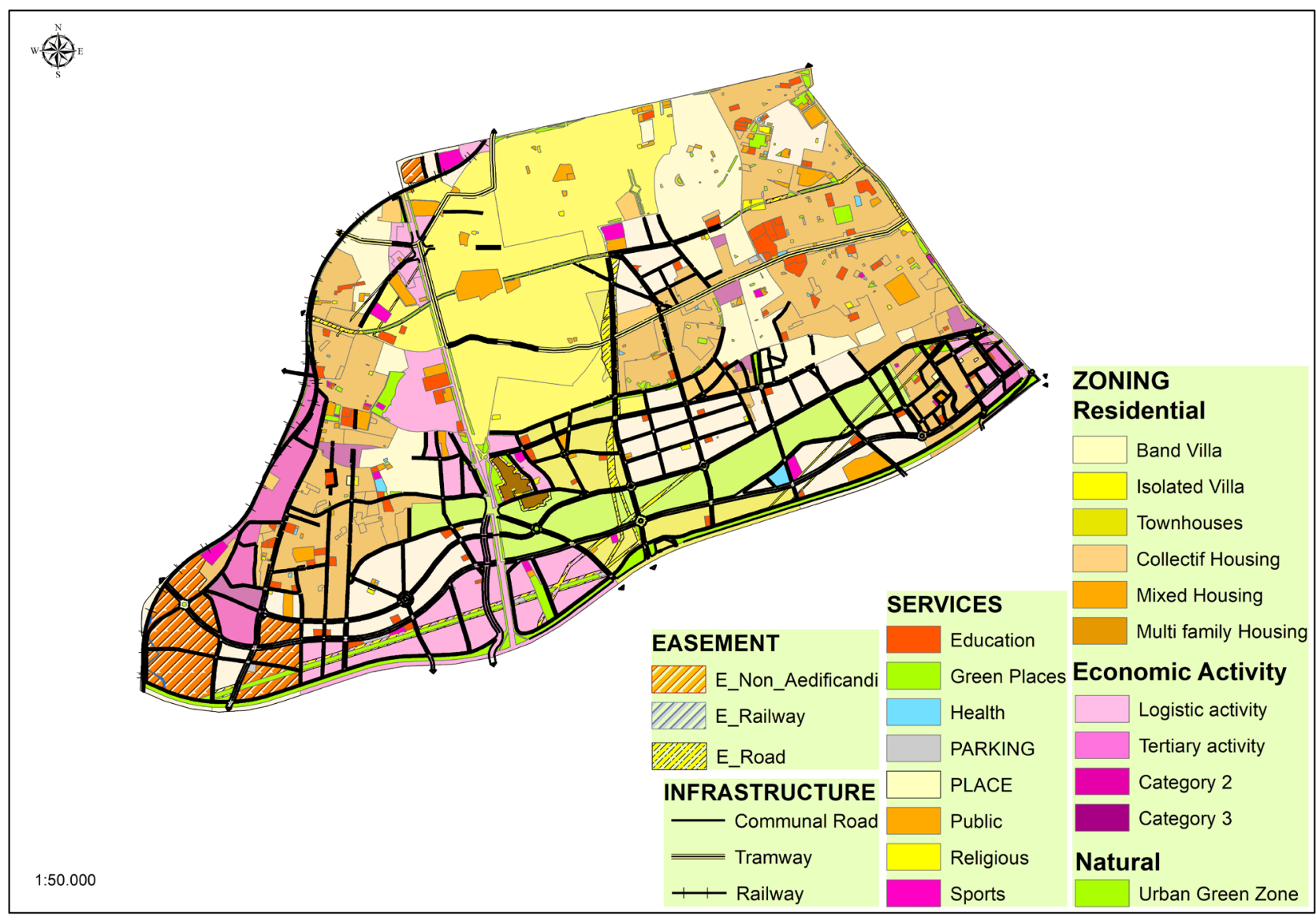

Figure 7. LUP of Ainchock.

This example may give evidence that LUP ontology model provides an efficient model for mapping and presenting the most relevant urban concepts at different data levels. We can conclude that our proposed model is valid for the representation of the most relevant concepts in the field of urban planning and the four dimensions make it possible to represent the territories according to all urban land use planning aspects.

\section{Conclusions}

This research study deals with the problematic of modeling ontology for urban planning. We proposed a multi-dimensional ontology model that will facilitate the interoperability between all urban planners and stakeholders in the field of urban planning. The novelty of our proposed model is the definition of the urban area not only based on the land use description but also by defining all important urban planning aspects within four dimensions: zoning, services, infrastructure and easement. The LUP ontology model presents the following characteristics:

- LUP provides semantic land use descriptions according to four dimensions: zoning, services, infrastructure and easement;

- LUP ontology defines about 100 relevant urban planning concepts according 
to Moroccan legislation and regulations;

- LUP model can be extended, reused and customized.

The LUP model was implemented using Protégé editor and tested with a specific case study on the municipality of "Ainchock" of Morocco. Future works intend to develop more our LUP ontology by adding more concepts and by detailing the classes with more properties and constraints to strengthen the description of urban areas.

\section{Conflicts of Interest}

The authors declare no conflicts of interest regarding the publication of this paper.

\section{References}

[1] Raffat, S.K., Siddiqui, M.S., Shaikh, Z.A. and Memon, A.R. (2012) Ontology: A Scientific Classification Technique. Sindh University Research Journal, 44, 63-68.

[2] Bragato Barros, T.H. and Gomes, D.L. (2018) Classification and Knowledge Organization Systems: Ontologies and Archival Classification. Proceedings of ISKO Conference Gomes, Porto, 9-11 July 2018, 103-111. https://doi.org/10.5771/9783956504211-103

[3] Zhao, Y., Dong, J. and Peng, T. (2009) Ontology Classification for Semantic-Web-Based Software Engineering. IEEE Transactions on Services Computing, 2, 303-317.

[4] Stanford Encyclopedia of Philosophy (2011) Aristotle's Metaphysics. http://plato.stanford.edu/entries/aristotle-metaphysics

[5] Ederton, H.B. (2001) A Mathematical Introduction to Logic. Second Edition, Elsevier, Amsterdam.

[6] Rastier, F. (2004) Ontologie(s). Revue des sciences et technologies de P information, série: Revue d Intelligence artificielle, 18, 15-40. https://doi.org/10.3166/ria.18.15-40

[7] Bachimont, B., Nadah, N., Baneyx, A. and Charlet, J. (2008) Categorial Ontologies: Formalizing the Differential Ontology. In: Benslimane, D., Ed., 2e Journées Francophones sur les Ontologies, ACM, Lyon.

[8] Bachimont, B. (2004) Digital Arts and Sciences: Knowledge Engineering and Criticism of Computational Reason. Ph.D. Thesis, University of Compiègne, Compiègne.

[9] Gruber, T.R. (1993) A Translation Approach to Portable Ontology Specifications. Knowledge Acquisition, 5, 199-220. https://doi.org/10.1006/knac.1993.1008

[10] Métral, C., et al. (2009) Ontology-Based Approaches for Improving the Interoperability between 3D Urban Models. Journal of Information Technology in Construction, 15, 169-184.

[11] Declerck, G. and Charlet, J. (2011) Intelligence Artificielle, ontologies et connaissances en médecine. Les limites de la mécanisation de la pensée. Revue des Sciences et Technologies de IInformation Série RIA: Revue d Intelligence Artificielle, Lavoisier, 25, 445-472. https://doi.org/10.3166/ria.25.445-472

[12] Métral, C., Falquet, G. and Karatsas, K. (2008) Ontologies for the Integration of Air Quality Models and 3D City Models. Conceptual Models for Urban Practitioners. 2nd Workshop of the COST Action C21, Turin, Italy, December 2008, 1-16. https://arxiv.org/ftp/arxiv/papers/1201/1201.6511.pdf 
[13] Abu-Lughod, J.L. (1990) Rabat: Urban Apartheid in Morocco. Princeton University Press, Princeton, 131-216, 2004.

[14] Dahir $\mathrm{n}^{\circ} 1-92-31$ du 15 hija 1412 (1992) Portant promulgation de la loi $\mathrm{n}^{\circ} 12-90$ relative à l'urbanisme. http://adala.justice.gov.ma/production/html/Fr/74593.htm

[15] LBCS: American Planning Association. Land Based Classification Standards. http://www.planning.org/lbcs

[16] Montenegro, N., Gomes, J.C., Urbano, P. and Duarte, J.P. (2012) A Land Use Planning Ontology: LBCS. Future Internet, 4, 65-82. https://doi.org/10.3390/fi4010065

[17] Duarte, J.P., Beirão, J.N., Montenegro, N. and Gil, J. (2012) City Induction: Formulating, Generating, and Evaluating Urban Plans. Communications in Computer and Information Science, 242, 73-98. https://doi.org/10.1007/978-3-642-29758-8 5

[18] Roussey, C., Laurini, R., Beaulieu, C., Tardy, Y. and Zimmerman, M. (2004) Towntology: Un retour d'expérience pour la construction d'une ontologie urbaine. Revue Internationale de Géomatique, 14, 217-237.

[19] European Co-Operation in the Field of Scientific and Technical Research. http://www.cost.eu

[20] Teller, J., Billen, R. and Cutting-Decelle, A.F. (2010) Bringing Urban Ontologies into Practice. Journal of Information Technology in Construction, 15, 108-110.

[21] COST UCE Action C21: Urban Ontologies for an Improved Communication in UCE Projects-Towntology.

https://web.archive.org/web/20140518021618/http://www.towntology.net

[22] Berdier, C. and Roussey, C. (2007) Urban Ontologies: The Towntology Prototype towards Case Studies. In: Teller, J., Lee, J.R. and Roussey, C., Eds., Ontologies for Urban Development, Studies in Computational Intelligence, Vol. 61, Springer, Berlin, 143-155. https://doi.org/10.1007/978-3-540-71976-2 13

[23] Kaza, N. and Hopkins, L.D. (2007) Ontology for Land Development Decisions and Plans, Studies in Computational Intelligence. In: Teller, J., Lee, J.R. and Roussey, C., Eds., Ontologies for Urban Development, Studies in Computational Intelligence, Vol. 61, Springer, Berlin, 47-59. https://doi.org/10.1007/978-3-540-71976-2 5

[24] Mtral, C., et al. (2007) An Ontology-Based Model for Urban Planning Communication. In: Teller, J., Lee, J.R. and Roussey, C., Eds., Ontologies for Urban Development, Studies in Computational Intelligence, Vol. 61, Springer, Berlin, 61-72. https://doi.org/10.1007/978-3-540-71976-2 6

[25] HarmonISA-Harmonisation of Land-Use Data. http://harmonisa.uni-klu.ac.at

[26] Protégé, Free Open-Source Ontology Editor and Framework for Building Intelligent Systems. https://protege.stanford.edu

[27] Kapoor, B. and Sharma, S. (2010) A Comparative Study Ontology Building Tools for Semantic Web Applications. International Journal of Web \& Semantic Technology, 1, 1-13. https://doi.org/10.5121/ijwest.2010.1301

[28] Degbelo, A. (2017) A Snapshot of Ontology Evaluation Criteria and Strategies. Semantics Conference, Amsterdam Netherlands, September 2017, 1-8. https://doi.org/10.1145/3132218.3132219

[29] Vrandecic, D. (2009) Ontology Evaluation. In: Staab, S. and Studer, R., Eds., Handbook on Ontologies, Springer, Berlin, 293-313.

[30] Kehagias, D.D., Papadimitriou, I., Hois, J., Tzovaras, D. and Bateman, J. (2008) A 
Methodological Approach for Ontology Evaluation and Refinement. The 2nd International Conference of ASK-IT, Nuremberg, 1-19.

[31] Hammar, K. and Sandkuhl, K. (2010) The State of Ontology Pattern Research: A Systematic Review of ISWC, ESWC and ASWC 2005-2009. Proceedings of the 2nd International Workshop on Ontology Patterns, Shanghai, January 2010, 5-17. 